\title{
DESAIN SISTEM INFORMASI IZIN USAHA PERIKANAN TANGKAP (STUDI KASUS PADA DINAS KELAUTAN DAN PERIKANAN KABUPATEN PENAJAM PASER UTARA)
}

\author{
Ahmad Rofiq Hakim ${ }^{1)}$, Siti Lailiyah ${ }^{2)}$, Rahmat Mujahidin ${ }^{3)}$ \\ Teknologi Informasi, Politeknik Negeri Samarinda ${ }^{1)}$ \\ Teknik Informatika, STMIK Widya Cipta Dharma ${ }^{2}$ \\ Sistem Informasi, STMIK Widya Cipta Dharma ${ }^{3)}$ \\ E-mail : rofiq93@polnes.ac.id ${ }^{1)}$, lail.59a@ gmail.com ${ }^{2)}$, Mattboyz_88@yahoo.co.id ${ }^{3)}$
}

\begin{abstract}
Abstrak - Penelitian dilakukan untuk membuat sebuah analisis dan desain sistem informasi izin usaha perikanan tangkap guna membantu Dinas Kelautan dan Perikanan Kabupaten Penajam Paser Utara dalam melakukan proses pembuatan izin usaha perikanan. Penelitian ini dilakukan melalui model air terjun (waterfall model) dan menggunakan tools desain Flow of Document (FOD), Context Diagram dan Data Flow Diagram (DFD). Adapun hasil akhir dari penelitian ini yakni berupa desain sistem informasi izin usaha perikanan tangkap
\end{abstract}

Kata kunci: Sistem Informasi, izin Usaha, Perikanan Tangkap

\section{PENDAHULUAN}

Indonesia dengan luas lautan sekitar 5,8 juta $\mathrm{km}^{2}$ dan panjang pantai kurang lebih $81.000 \mathrm{~km}$ memiliki potensi pendapatan ekonomi dari bidang perikanan cukup besar. Begitu pula dengan kabupaten Penajam Paser Utara yang merupakan kabupaten yang berada di provinsi Kalimantan Timur dengan luas wilayah 3.333,06 $\mathrm{Km}^{2}$, panjang garis pantai 400,18 $\mathrm{Km}^{2}$, menjadikan Kabupaten Penajam Paser Utara merupakan salah satu wilayah potensial usaha perikanan di Provinsi Kalimanatan Timur.

Sebagaimana tercantum dalam Peraturan Menteri Kelautan dan Perikanan Republik Indonesia Nomor PER.30/MEN/ 2012. Yang berbunyi:

1) bahwa sumber daya ikan di Wilayah Pengelolaan Perikanan Negara Republik Indonesia (WPP-NRI) yang merupakan bagian dari kekayaan bangsa Indonesia, perlu dilakukan pengelolaan yang optimal dan berkelanjutan serta terjaminnya kelestarian sumber daya ikan dan lingkungannya untuk terwujudnya industrialisasi perikanan tangkap.

2) bahwa dalam rangka pemanfaatan sumber daya ikan secara optimal bagi kemakmuran rakyat Indonesia, perlu mengatur kembali usaha perikanan tangkap sebagaimana diatur dalam Peraturan Menteri Kelautan dan Perikanan Nomor PER.14/MEN/2011 tentang Usaha Perikanan Tangkap sebagaimana telah diubah dengan Peraturan Menteri Kelautan dan Perikanan Nomor PER.49/MEN/2011;

3) bahwa berdasarkan pertimbangan sebagaimana dimaksud pada nomor 1 dan nomor 2, perlu mengatur Usaha Perikanan Tangkap di Wilayah Pengelolaan Perikanan Negara Republik Indonesia dengan Peraturan Menteri.

Sesuai dengan Peraturan Menteri di atas Dinas Kelautan dan Perikanan Kabupaten Penajam Paser Utara telah menjalankan sistem perizinan tersebut dan sudah menggunakan sistem yang terkomputerais namun masih menggunakan aplikasi microsoft office yang ada, seperti Ms. Word, Ms. Excel. Sehingga dalam pembuatan izin usaha masih kurang optimal dan banyak memakan waktu dalam pencarian data.

Dari masalah yang ditemukan di lapangan perlu dibuat suatu aplikasi sistem yang terkomputerisasi dimana di dalam ya memuat data perizinan di dalam suatu database, pembuatan surat perizinan dan tersedia laporan-laporan pengolahan data.

\section{RUANG LINGKUP PENELITIAN}

Berdasarkan uraian pada latar belakang tersebut maka permasalahan dalam penelitian ini adalah "Bagaimana Mendesain Sistem Informasi Izin informasi izin usaha perikanan tangkap", dengan studi kasus di Dinas Kelautan dan Perikanan Kabupaten Penajam Paser Utara

Penelitian ini dibatasi pada ruang lingkup yaitu

1) Izin usaha untuk perikanan tangkap yang pengurusannya pada tingkat Kabupaten/Kota dalam hal ini di tangani oleh Dinas Kelautan dan Perikanan Kabupaten yaitu Kapal dengan ukuran maksimal 10GT

2) Studi kasus penelitian ini di Dinas Kelautan dan Perikanan Kabupaten Penajam Paser Utara. 
3) Model pengembangan sistem yang digunakan adalah waterfall model

\section{IZIN USAHA PERIKANAN TANGKAP}

Peraturan Menteri Kelautan dan Perikanan Nomor 30 Tahun 2012. Perizinan perikanan tangkap merupakan salah satu layanan yang diberikan Kementerian Kelautan dan Perikanan kepada masyarakat (perorangan/koperasi/ perusahaan swasta nasional) yang ingin mengajukan permohonan perizinan kegiatan usaha perikanan tangkap di Wilayah Pengelolaan Perikanan Republik Indonesia dan laut lepas, yang meliputi ijin usaha perikanan (SIUP), ijin penangkapan ikan (SIPI), ijin pengangkutan ikan (SIKPI), dan ijin penangkapan serta pengangkutan ikan dalam satuan armada penangkapan ikan.

Surat Izin Usaha Perikanan (SIUP) adalah izin tertulis yang harus dimiliki untuk melakukan us aha perikanan dengan menggunakan sarana produksi yang tercantum dalam izin tersebut.

Surat Izin Penangkapan Ikan (SIPI) adalah izin tertulis yang harus dimiliki setiap kapal perikanan untuk melakukan penangkapan ikan yang merupakan bagian tidak terpisahkan dari SIUP. Adapun SIPI digunakan untuk kapal penangkap ikan berukuran 6 GT keatas.

Surat Izin Kapal Pengangkut Ikan (SIKPI) adalah izin tertulis yang harus dimiliki setiap kapal perikanan untuk melakukan pengangkutan ikan yang merupakan bagian tidak terpisahkan dari SIUP. Adapun SIPI digunakan untuk kapal pengangkut ikan berukuran 6 GT ke atas.

Bukti Pencatatan Kapal Perikanan (BPKP) adalah izin tertulis yang harus dimiliki setiap kapal perikanan untuk nelayan kecil. Adapun BPKP digunakan untuk kapal dengan ukuran dibawah 6 GT

Adapun syarat untuk memiliki SIUP sebagaimana dimaksud dalam Pasal 14 ayat (2) harus mengajukan permohonan kepada Direktur Jenderal, dengan melampirkan persyaratan:

1) Rencana usaha meliputi rencana investasi, rencana kapal, dan rencana operasional;

2) Fotokopi Nomor Pokok Wajib Pajak (NPWP) pemilik kapal atau perusahaan, dengan menunjukkan aslinya;

3) Fotokopi Kartu Tanda Penduduk (KTP) pemilik kapal atau penanggung jawab perusahaan, dengan menunjukkan aslinya;

4) Surat keterangan domisili usaha;

5) Fotokopi akta pendirian perusahaan dengan menunjukkan aslinya;

6) Fotokopi pengesahan badan hukum bagi perusahaan perikanan yang
7) Menggunakan kapal penangkap ikan dan/atau kapal pengangkut ikan dengan jumlah kumulatif 200 (dua ratus) GT keatas;

8) Surat pernyataan bermeterai cukup dari pemilik kapal atau penanggung jawab perusahaan yang menyatakan:

(1) Kesanggupan membangun atau memiliki UPI atau bermitra dengan UPI yang telah memiliki Sertifikat Kelayakan Pengolahan (SKP) bagi usaha perikanan tangkap terpadu;

(2) Kesediaan mematuhi dan melaksanakan semua ketentuan peraturan perundangundangan; dan kebenaran data dan informasi yang disampaikan.

\section{SISTEM INFORMASI}

Menurut Bonnie Soeherman dan Marion Pinontoan (2008, 5), dalam (Mustikowati, Purnama, \& Sukadi, 2012) mengatakan bahwa sistem informasi merupakan serangkaian komponen berupa manusia, prosedur, data, dan teknologi (seperti komputer) yang digunakan untuk melakukan sebuah proses untuk pengambilan keputusan guna penunjang keberhasilan bagi setiap organisasi (dalam pencapaian tujuan).

Sistem informasi merupakan sistem, yang berisi jaringan SPD (sistem pengolahan data), yang dilengkapi dengan kanal-kanal komunikasi yang digunakan dalam sistem organisasi data. Elemen proses dari sistem informasi antara lain mengumpulkan data (data gathering), mengelola data yang tersimpan, menyebarkan informasi, menurut Witarto (2004:19), dikutip dalam (Setyawan, Purnama, \& Sukandi, 2012).

Menurut Leman (1998), dikutip dalam (Nursahid, Riasti, \& Purnama, 2012). Komponen sistem informasi terdiri dari :

1) Hardware (perangkat keras), terdiri dari komputer, printer dan jaringan.

2) Software, kumpulan perintah yang ditulis dengan aturan untuk memerintah komputer melaksanakan tugas tertentu.

3) Data, merupakan komponen dasar dari informasi yang akan diproses lebih lanjut untuk menghasilkan informasi.

4) Manusia, yang terlibat dalam komponen manusia seperti operator dan pimpinan.

5) Prosedur, dokumentasi proses sistem buku penuntun operasional (aplikasi) dan teknis.

\section{METODE AIR TERJUN}

Metode the Classic Life Cycle (SDLC) atau pada umumnya dikatakan paradigma water fall. Pada metode ini terdapat 5 (lima) tahap untuk mengembangkan suatu perangkat lunak. Kelima tahapan itu tersusun dari atas kebawah , diantaranya 
Hakim dkk., Desain Sistem Informasi Izin Usaha Perikanan Tangkap (Studi Kasus Pada Dinas Kelautan dan Perikanan Kabupaten Penajam Paser Utara)

Analisis, Design, coding, Teyysting, dan Maintenance. Konsep dari metode ini adalah melihat bagaimana suatu masalah secara sistematis dan terstruktur dari atas kebawah. Tahap-tahap pengembangan perangkat lunak metode water fall dapat dilihat pada gambar 1

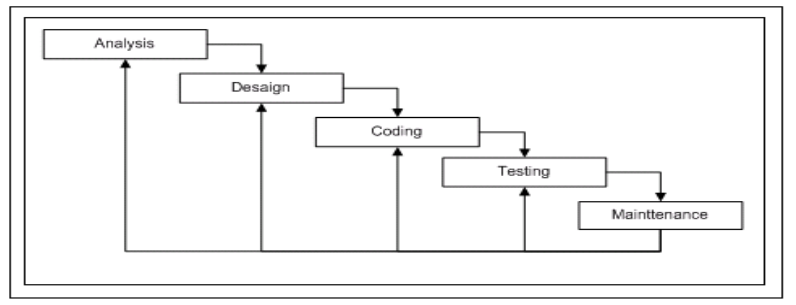

Gambar 1 Metode The Classic Life Cycle/Waterfall

Sumber : Simarmata (2010), Rekayasa Perangkat Lunak

Berikut ini akan diuraikan tahap-tahap pengembangan perangkat lunak dengan menggunakan metode waterfall, yaitu:

1) Analisis adalah tahapan menganalisa hal-hal yang diperlukan dalam pelaksanaan proyek pembuatan atau pengembangan software. Dalam hal ini analisis yang dilakukan dengan menganalisa dokumen-dokumen yang digunakan pada bagian administrasi.

2) Desaign adalah penterjemahan dari keperluan-keperluan yang dianalisis dalam bentuk yang lebih mudah dimengerti oleh pemakai.

3) Coding adalah tahap penterjemah data/pemecahan masalah software yang telah dirancang dalam bahasa pemograman yang telah ditentukan. Pada tahap ini bahasa pemograman yang digunakan dalam pembuatan sistem adalah Microsoft Visual Basic.

4) Testing adalah tahap pengujian terhadap program yang telah dibuat. Pengujian ini dimulai dengan membuat suatu uji kasus untuk setiap fungsi pada perangkat lunak untuk aplikasi perhitungan anggaran biaya pelatihan kemudian dilanjutkan pengujian terhadap modul-modul dan terakhir pada tampilan antar muka untuk memastikan tidak ada kesalahan dan semua berjalan dengan baik dan input yang diberikan hasilnya sesuai dengan yang diinginkan.

5) Maintenance adalah perangkat yang telah dibuat dapat mengalami perubahan sesuai permintaan pemakai. Pemeliharaan dapat dipakai jika ada permintaaan penambahan fungsi sesuai dengan keinginan pemakai ataupun adanya pertubuhan dan perkembangan baik perngakat lunak maupun perangkat keras.

\section{ANALISIS}

\section{1) Anaisis User}

Hasil analisis user yang akan ikut terlibat di salam sistem yaitu:

[1] Administrator (Administrasi)

Memiliki hak akses sebagai berikut :

a. Dapat menginput data pada Pemohon, Kapal, SIUP, SIPI, SIKPI, BPKP

b. Dapat melihat dan mencetak laporan diantaranya laporan pemohon, laporan SIUP, laporan SIPI, SIKPI, dan laporan BPKP.

c. Dapat memonitoring izin SIPI, SIKPI, dan BPKP yang sudah dan belum melakukan perpanjang

[2] User (KASI)

Memiliki hak akses sebagai berikut :

a. Dapat menginput data pada form Pemohon

[3] Pimpinan

Memiliki hak akses sebagai berikut :

a. Dapat melihat dan mencetak laporan diantaranya laporan pemohon, laporan SIUP, laporan SIPI, SIKPI, dan laporan BPKP.

b. Dapat memonitoring izin SIPI, SIKPI, dan BPKP yang sudah dan belum melakukan perpanjang

\section{2) Anaisis Informasi}

Informasi yang akan ditampilkan pada sistem informasi izin usaha perikanan tangkap diantaranya :

[1] Data Pemohon, Data Kapal, Data SIUP, Data SIPI, Data SIKPI, Data BPKP

[2] Laporan yang memberikan informasi tentang data yang terdiri dari pemohon, data SIUP, data SIPI, data SIKPI, dan data BPKP pada Dinas Kelautan dan Perikanan

[3] Monitoring memberikan informasi tentang memonitoring izin SIPI, SIKPI, dan BPKP yang sudah dan belum melakukan perpanjangan.

\section{3) Analisis Data}

Berdasarkan hasil Analisis Data, maka data yang dibutuhkan adalah :

[1] Data Nelayan yaitu : Kode Nelayan, Nama Nelayan, Alamat, Telepon, Fax, Email, NPWP, No KTP

[2] Data Perusahaan meliputi : Kode Nelayan, Nama Nelayan, Alamat, Telepon, Fax, E-mail, NPWP, No KTP, Penanggung Jawab, No Akte 
[3] Data Kapal meliputi : Nama Kapal, Nama Panggilan Kapal, Tempat No. Grose, Tempat No. Buku, Tanda Selar, Tanda Pengenal, Radio Panggil, Tahun Pembuatan, Tempat Pembuatan, Bahan Casco, Berat Kotor, Berat Bersih, Merk Mesin, No. Seri Mesin, Kekuatan Mesin

\section{DESAIN SISTEM}

\section{1) Flow Of Document (FOD)}

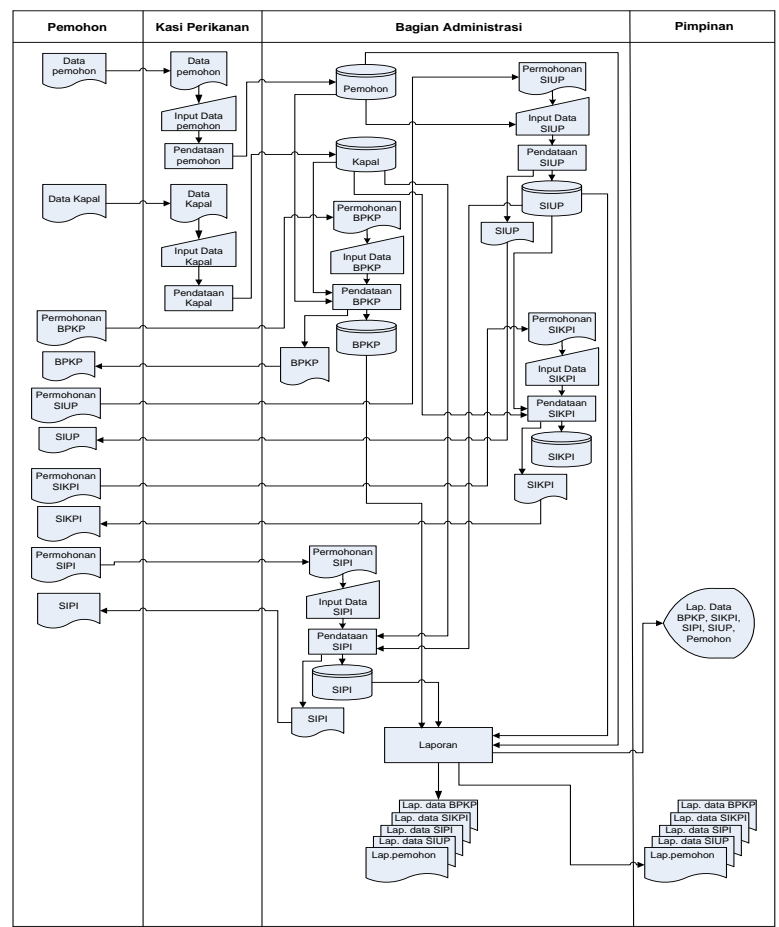

Gambar 2. Desain Flow Of Document (FOD) Sistem

Pada gambar 2 dapat dilihat desain Flow of Document sistem informasi izin usaha perikanan tangkap, bahwa pemohon memberikan data pemohon dan data kapal kepada bagian Kasi perikanan untuk dilakukan proses pendataan pemohon dan hasilnya disimpan di master data pemohon dan di master data kapal. Pemohon juga memberikan data permohonan SIUP kepada Bagian Administrasi untuk dilakukan proses pendataan SIUP dan hasilnya disimpan di master data SIUP dan form SIUP yang diserahkan kepada pemohon. Pemohon memberikan data permohonan SIPI kepada Bagian Administrasi untuk dilakukan proses pendataan SIPI dan hasilnya disimpan di master data SIPI dan form SIPI yang diserahkan kepada pemohon.

Pemohon memberikan data permohonan SIKPI kepada Bagian Administrasi untuk dilakukan proses pendataan SIKPI dan hasilnya disimpan di master data SIKPI dan form SIKPI yang diserahkan kepada pemohon. Pemohon juga memberikan data permohonan BPKP kepada Bagian Administrasi untuk dilakukan proses pendataan BPKP dan hasilnya disimpan di master data BPKP dan form BPKP yang diserahkan kepada pemohon.

Dari semua master data yang dihasilkan oleh masing-masing proses kemudian dilakukan proses pembuatan laporan. Laporan yang dihasilkan yaitu laporan data pemohon, laporan data kapal, laporan data SIUP, laporan data SIPI, laporan data SIKPI dan laporan data BPKP. Laporan-laporan tersebut kemudian diberikan kepada pimpinan untuk diperiksa dan disetujui.

\section{2) Data Flow Diagram (DFD)}

\section{[1] Context Diagram (CD)}

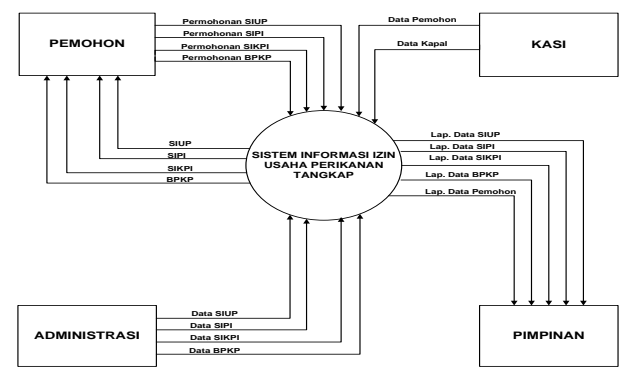

Gambar 3. Context Diagram

Pada gambar 4 terdapat empat buah entitas yaitu entitas pemohon, kasi, administrasi dan pimpinan. Entitas pemohon memberikan empat buah data yaitu, data permohonan SIUP, permohonan SIPI, permohonan SIKPI dan permohonan BPKP. Selain itu pemohon juga mendapatkan empat buah output yaitu SIUP, SIPI, SIKPI dan BPKP. Dan entitas Kasi memberikan data pemohon dan data kapal.

Entitas administrasi memberikan data SIUP, data SIPI, data SIKI, dan data BPKP.

Entitas pimpinan mendapatkan laporan-laporan yaitu laporan data pemohon, laporan data SIUP, laporan data SIPI, laporan data SIKPI dan laporan data BPKP.

\section{[2] Data Flow Diagram (DFD) Level 0}

Pada gambar 4 Data flow Diagram level 0 terdapat empat buah entitas yaitu entitas kasi, entitas administrasi, entitas pemohon dan entitas pimpinan. Selain itu, juga terdapat enam buah proses komputerisasi.

Pada proses pendataan pemohon, data yang masuk ke sistem yaitu data pemohon dan hasilnya disimpan ke data store pemohon. Pada proses pendataan SIUP, data yang masuk ke sistem yaitu data permohonan SIUP dan hasilnya disimpan ke dalam data store SIUP serta form SIUP yang diserahkan kepada entitas pemohon. Pada proses pendataan SIPI, data yang masuk ke sistem yaitu data permohonan SIPI dan hasilnya disimpan ke 
Hakim dkk., Desain Sistem Informasi Izin Usaha Perikanan Tangkap (Studi Kasus Pada Dinas Kelautan dan Perikanan Kabupaten Penajam Paser Utara)

dalam data store SIPI serta form SIPI yang diserahkan kepada entitas pemohon.

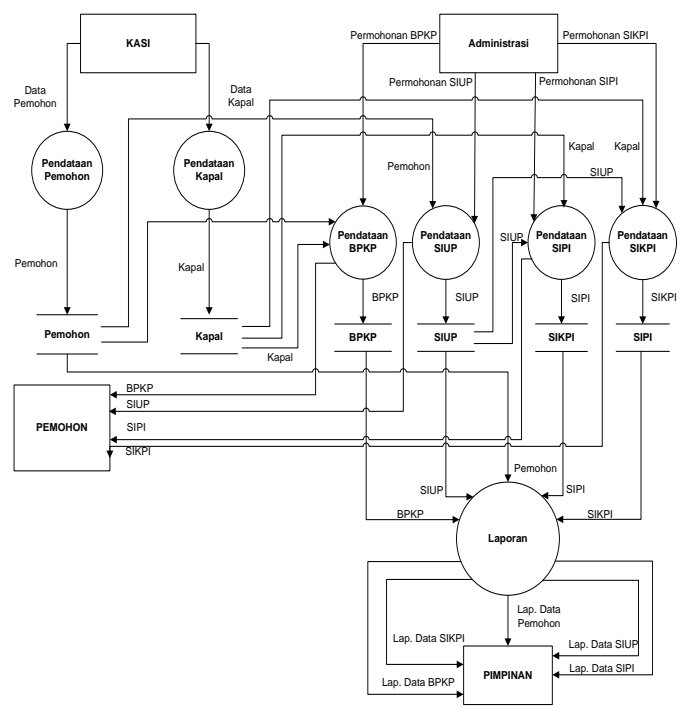

Gambar 4. Data Flow Diagram (DFD) Level 0

Pada proses pendataan SIKPI, data yang masuk ke sistem yaitu data permohonan SIKPI dan hasilnya disimpan ke dalam data store SIKPI serta form SIKPI yang diserahkan kepada entitas pemohon. Pada proses pendataan BPKP, data yang masuk ke sistem yaitu data permohonan BPKP dan hasilnya disimpan ke dalam data store BPKP serta form BPKP yang diserahkan kepada entitas pemohon.

Dari semua data store kemudian dilakukan proses pembuatan laporan. Laporan yang dihasilkan yaitu laporan data pemohon, laporan data SIUP, laporan data SIPI, laporan data SIKPI dan laporan data BPKP. Laporan-laporan tersebut kemudian diberikan kepada pimpinan untuk diperiksa dan disetujui.

[3] Data Flow Diagram (DFD) Level 1 Proses Laporan

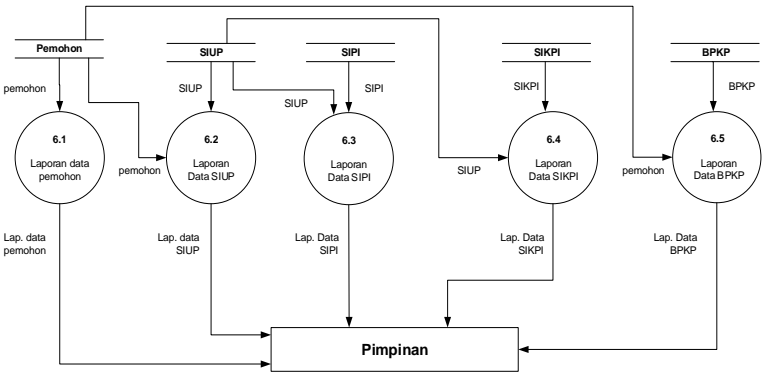

Gambar 5. Data Flow Diagram (DFD) Level 1

Pada gambar 5, Data Flow Diagram Level 1 Proses Laporan, terdapat lima buah proses laporan yaitu proses laporan data pemohon, laporan data
SIUP, laporan data SIPI, laporan data SIKPI dan proses laporan data BPKP. Selain itu terdapat lima data store yaitu data store pemohon, data store SIUP, data store SIPI, data store SIKPI dan data store BPKP. Laporan yang dihasilkan yaitu laporan data pemohon, laporan data SIUP, laporan data SIPI, laporan data SIKPI dan laporan data BPKP yang diberikan kepada pimpinan untuk diperiksa dan disetujui.

[4] DFD Level 1 Cetak Form SIUP, SIPI, SIKPI dan BPKP

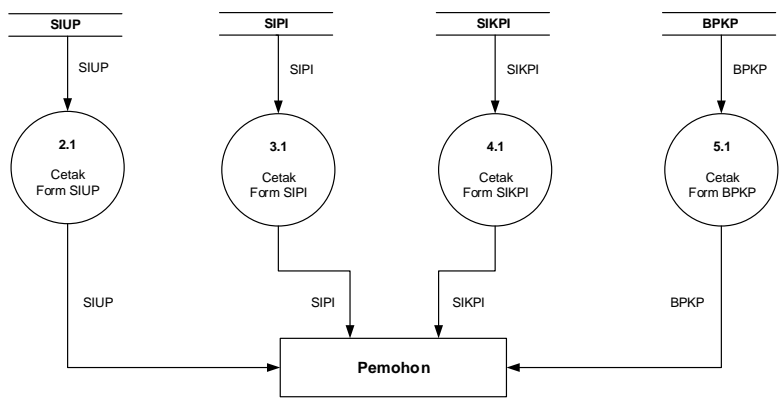

Gambar 6. DFD Level 1 Cetak Form SIUP, SIPI, SIKPI dan BPKP

Pada gambar 6, Data Flow Diagram Level 1, terdapat proses cetak form SIUP, cetak form SIPI, cetak form SIKPI dan cetak form BPKP. Data store yang digunakan yaitu SIUP, SIPI, SIKPI dan BPKP. Output yang dihasilkan yaitu form SIUP, SIPI, SIKPI dan BPKP yang diberikan kepada pemohon.

\section{3) Desain Antarmuka Pengguna}

\section{[1] Form Pemohon}

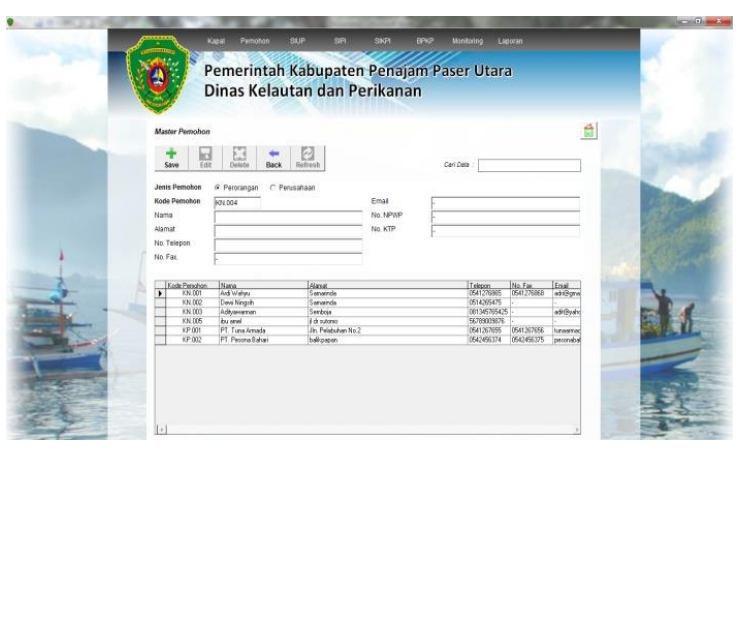




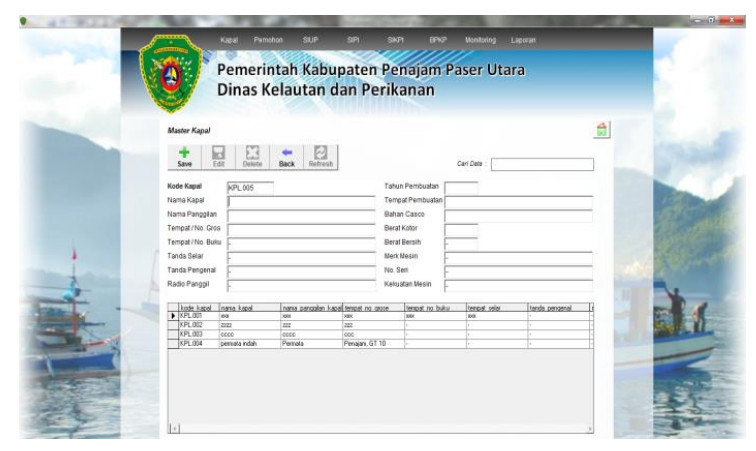

[2] Form SIUP

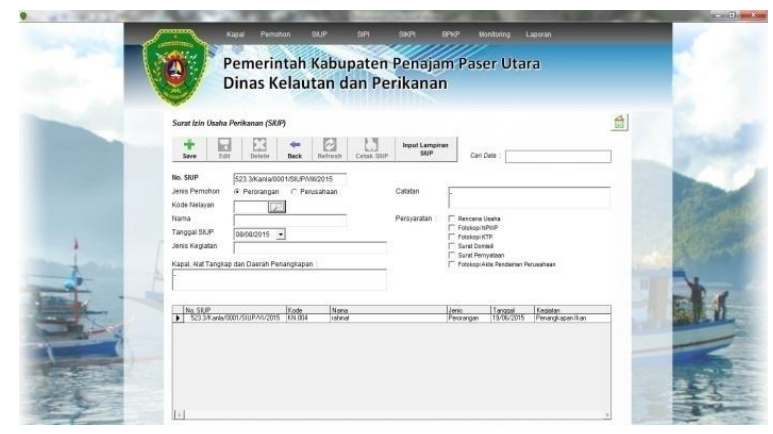

[3] Form SIPI

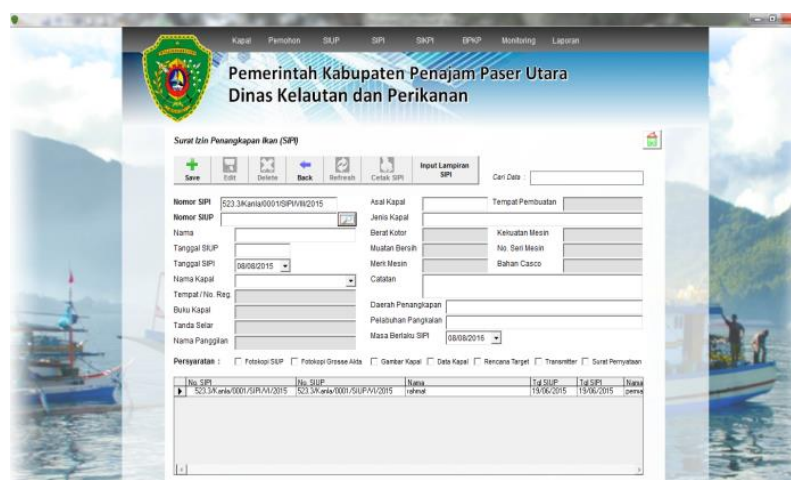

[4] Form SIKPI

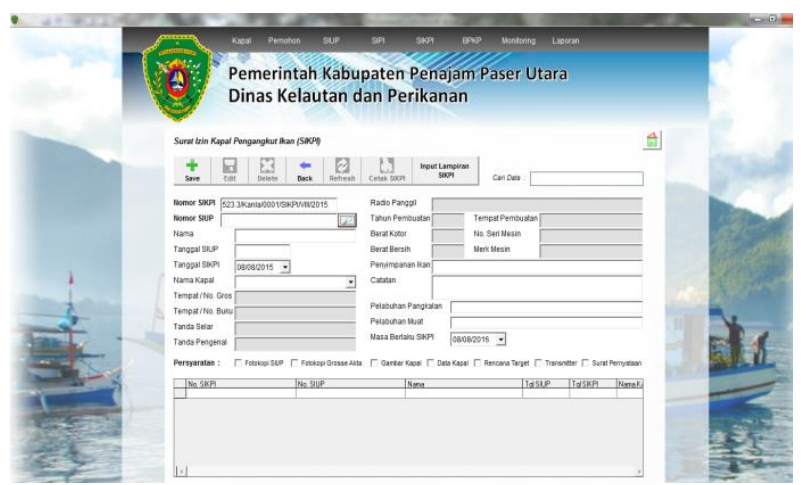

\section{[5] Form BPKP}

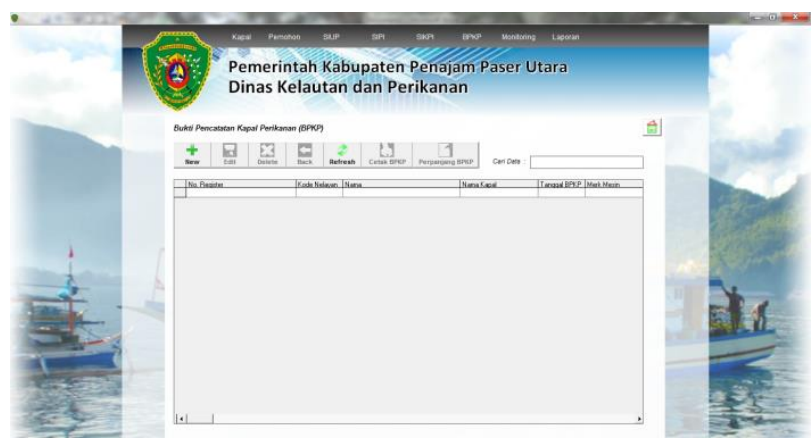

\section{KESIMPULAN}

1) Untuk mendesain Sistem Informasi Izin Usaha Perikanan Tangkap dapat digunakan model air terjun (waterfall model)

2) Desain Sistem Informasi Izin Usaha Perikanan Tangkap akan menangani pengurusan perizinan perikanan tangkap sampai 10 GT yang dikelola oleh Dinas Perikanan Kabupaten/Kota

3) Adapun Izin yang akan dikelola meliputi SIUP, SIPI, SIKPI, BPKP

\section{Daftar Pustaka}

[1] Connoly dan begg, 2005, database system: A practical approach to design, implementation, and management, 4th edition

[2] Jogiyanto. H.M, 2005. Analisa dan Sistem Informasi: Pendekatan Terstruktur Teori dan Praktek Aplikasi Bisnis, Yogyakarta : Andi Offset.

[3] Jogiyanto. HM, 2008, Analisis dan Desain Sistem Informasi Edisi Ketiga, Cetakan Kedua, Yogyakarta : Andi Offset.

[4] Janner, Simarmata, 2010, Rekayasa Perangkat Lunak, Yogyakarta: Andi Offset

[5] Kadir, Abdul, 2007, Konsep dan Tuntunan Praktis Basis Data, Yogyakarta: Andi Offset.

[6] Kadir, Abdul, 2009, Mudah Mempelajari Database Mysql, Yogyakarta: Andi Offset.

[7] Kadir, Abdul, 2009,Dasar Perancangan dan Implementasi Database Relasional, Yogyakarta: Andi Offset.

[8] Peraturan Menteri Kelautan dan Perikanan Nomor PER. 30/ Men/ 2012 Tentang Usaha Perikanan Tangkap Diwilayah Pengelolaan Perikanan Negara Republik Indonesia. 